\title{
ANALISIS YURIDIS PEMBATALAN PERDA OLEH MENTERI DALAM NEGERI
}

\author{
Novira Maharani Sukma \\ Fakultas Hukum Universitas Diponegoro \\ Jl. Prof. H. Soedarto, S.H. Tembalang, Semarang \\ Email: noviramaharani@gmail.com
}

\begin{abstract}
Abstrak
Penerapan sistem otonomi yang diamanatkan UUD NRI 1945 berimplikasi pada terbaginya kekuasaan pemerintah pusat pada pemerintah daerah. Berdasarkan hal tersebut pemerintah daerah berhak membentuk perda untuk mengatur daerahnya, disinilah muncul salah satu peran pemerintah pusat dalam melakukan pengawasan dan pembinaan terhadap pemerintah daerah dengan melakukan pengawasan terhadap perda dengan cara melakukan pengujian perda (excecutive review). Pengujian perda tersebut bermuara pada mekanisme pembatalan perda yang dianggap bertentangan dengan ketertiban umum dan hukum yang lebih tinggi. Namun disini terdapat inkonsisten yang dilakukan oleh pemerintah dalam menggunakan instrumen hukum untuk membatalkan perda. Menteri Dalam Negeri hanya berhak membatalkan Perda Provinsi dan peraturan Gubernur saja. tetapi dalam prakteknya, pembatalan perda secara keseluruhan dilakukan oleh Menteri dalam negeri dengan menggunakan Kepmendagri. Disinilah terjadi ketidakkonsistenan dari segi kewenangan dan penggunaan instrumen hukum oleh pemerintah dalam melakukan pembatalan perda.

Kata Kunci: Pembatalan, Perda, Undang-Undang
\end{abstract}




\section{Pendahuluan}

Indonesia telah menjalankan otonomi daerah secara luas sejak diberlakukannya Undang-Undang Nomor 22 Tahun 1999 sampai dengan saat ini dengan berlakunya Undang-Undang Nomor 23 Tahun 2014 tentang Pemerintahan Daerah. Pada era ini, Pemerintah Daerah bersama DPRD diberi kewenangan untuk membuat peraturan daerah menunjukkan adanya peluang bagi daerah mengatur wilayahnya sendiri demi memajukan dan memberdayakan secara optimal daerahnya.

Pemerintah Daerah dan DPRD dalam menyusun dan mengesahkan perda, perlu memperhatikan pada adanya tata urutan peraturan perundangundangan. Dengan demikian, perda harus berdasarkan atau memiliki dasar hukum dari peraturan perundang-undangan yang lebih tinggi tingkatannya. Perda tidak boleh bertentangan dengan kepentingan umum, perda lain, atau perundang-undangan yang lebih tinggi. Dalam kaitan dengan pengawasan represif, perda yang bertentangan dengan peraturan perundang-undangan yang lebih tinggi akan batal demi hukum atau dapat dibatalkan.

Adanya pengujian terhadap peraturan daerah yang dilakukan oleh pemerintah tidak sepenuhnya diterima baik oleh daerah, pada kenyataannya banyak daerah yang merasa keberatan jika peraturan daerah yang telah dibuat dengan susah payah, membutuhkan biaya yang banyak dan waktu yang lama pada akhirnya dibatalkan oleh Menteri Dalam Negeri, sehinga mereka berpendapat karena perda yang sudah disahkan dan dibuat dengan cara yang benar untuk kepentingan rakyat, tidak begitu saja dengan mudah untuk dibatalkan, dan seandainya dibatalkan pun harus melalui prosedur hukum yang sesuai dengan hierarki pembentukan peraturan perundang-undangan dalam 
Pasal 7 UU Nomor 12 Tahun 2011 tentang Pembentukan Peraturan PerundangUndangan yaitu:

1. Undang-undang Dasar Negara Kesatuan Republik Indonesia Tahun 1945

2. Ketetapan Majelis Permusyawaratan Rakyat

3. Undang-undang/Peraturan Pemerintah Pengganti Undang-undang

4. Peraturan Pemerintah

5. Peraturan Presiden

6. Peraturan daerah Provinsi

\section{Peraturan Daerah Kabupaten/Kota}

Prosedur yang dimaksud adalah melalui Mahkamah Agung RI karena Mahkamah Agung RI dapat melakukan judicial review terhadap peraturan daerah yang dinilai bermasalah untuk membuktikan apakah peraturan daerah-peraturan daerah itu bertentangan dengan peraturan perundang-undangan yang lebih tinggi derajatnya atau tidak.

Perdebatan mengenai berlakunya pengujian pembatalan terhadap Perda menjadi pertanyaan tersendiri di era otonomi daerah saat ini, mengingat Perda adalah produk kepala daerah dan DPRD di suatu daerah yang bersifat otonom sedangkan salah satu dampak positif berkembangnya ide otonomi daerah adalah menguatnya eksistensi Perda yang memungkinkan pengembangan segala potensi kekhasan daerah mendapat payung yuridis yang jelas.

Pembatalan peraturan daerah (perda) secara sepihak oleh pemerintah pusat, dalam hal ini oleh Kementerian Dalam Negeri, menimbulkan polemik di berbagai stakeholder. Tidak kurang dari 3.143 perda menjadi objek dari 
kewenangan Menteri Dalam Negeri (Mendagri) untuk membatalkan perda dari berbagai daerah di Indonesia. Mengingat Pasal 24A UUD Negara Republik Indonesia Tahun 1945 telah memberikan kewenangan menguji peraturan perundang-undangan di bawah undang-undang terhadap undang-undang kepada Mahkamah Agung, akan tetapi pada Pasal 251 Undang-Undang Nomor 23 Tahun 2014 tentang Pemerintahan Daerah memberikan kewenangan kepada Menteri Dalam Negeri sebagai wakil pemerintah pusat untuk membatalkan perda yang bertentangan dengan peraturan perundang-undangan yang lebih tinggi.

Peraturan perundang-undangan Indonesia menunjukkan dualisme pengujian Perda, yakni antara Mendagri dan Mahkamah Agung. Ni'matul Huda berpendapat pemerintah pusat sudah seharusnya tidak diberi kewenangan oleh Undang-Undang untuk menilai dan membatalkan Perda atas dasar bertentangan dengan peraturan perundang-undangan yang lebih tinggi. Sebab kewenangan pengujian sudah diberikan konstitusi kepada Mahkamah Agung. (Ni'matul Huda, $2010: 340)$

Pertanyaan yuridis yang mengemuka dari persoalan ini adalah berkenaan dengan keabsahan dari kewenangan Mendagri tersebut dan pengaruhnya terhadap kedudukan Perda sebagai suatu produk hukum. Dalam hal ini penulis menilai adanya aturan yang tidak sinkron yang mengatur tentang kewenangan pembatalan peraturan daerah. Dengan pertimbangan tersebut, diperlukan adanya suatu kajian yuridis normatif untuk menganalisis pembatalan peraturan daerah dalam praktik ketatanegaraan yang ada di Indonesia. 


\section{Pembahasan}

\subsection{Peraturan Daerah}

Peraturan daerah adalah peraturan perundang-undangan yang dibentuk oleh DPRD dengan persetujuan bersama Kepala Daerah. Melalui amandemen UUD 1945 yang kedua, perda mendapatkan landasan konstitusionalnya di dalam konstitusi yang keberadaannya digunakan untuk melaksanakan otonomi dan tugas pembantuan.

Peraturan Daerah merupakan produk hukum yang paling bawah dalam tata urutan peraturan perundang-undangan. Memahami kedudukan Peraturan Daerah dalam tata perundang-undangan ini menjadi penting agar dalam pembentukan Peraturan Daerah tidak bertentangan dengan peraturan perundang-undangan yang lebih tinggi sehingga dapat terhindar dari pembatalan atau dinyatakan tidak sah.Kedudukan perda dalam hierarki peraturan perundang-undangan di Indonesia, ada di dalam Undang-Undang Nomor 12 Tahun 2011 tentang Pembentukan Peraturan PerundangUndangan, yaitu:

1. Undang-Undang Dasar Negara Republik Indonesia Tahun 1945 (UUD NRI Tahun 1945);

2. Ketetapan Majelis Permusyawaratan Rakyat (Tap MPR);

3. Undang-Undang (UU) atau Peraturan Pemerintah Pengganti Undangundang (Perpu);

4. Peraturan Pemerintah (PP);

5. Peraturan Presiden (Perpres);

6. Peraturan Daerah Provinsi (Perda Provinsi);

7. Peraturan Daerah Kabupaten atau Kota (Perda Kabupaten atau kota). 
Melihat jenis dan hierarki peraturan perundang-undangan di atas, tentu saja ditafsirkan sebagaimana dalam penjelasan pasal tersebut dimaksud, bahwa kekuatan hukum daripada Perda otomatis bergantung dan berada di bawah peraturan perundang-undangan di atasnya. Jimly Asshiddiqiemenyatakan bahwa Perda sejatinya tak pernah dianggap berbeda dengan produk UU yang dibuat oleh pusat, yang membedakan di antara keduanya bukanlah materi muatan ataupun isi, akan tetapi ruang linkup keberlakuan dari masing-masing produk perundang-undangan tersebut, istilah Perda sendiri dapat dimaknai UU lokal (locale statue/locale wet) yaitu Undang-Undang yang bersifat lokal. (Jimly Asshiddiqie, $2010: 63$ ) Substansi materi daripada Perda tidak diperkenankan untuk bertentangan dengan materi dari peraturan perundag-undangan di atasnya.

\subsection{Mekanisme Executive Review Pembatalan Perda}

Seperti layaknya peraturan perundang-undangan yang lain, pembentukan Perda tidak lepas dari pengawasan dan pengendalian. Hal ini berkenaan dengan kontrol terhadap norma hukum yang terdapat dalam peraturan perundang-undangan, melalui apa yang biasa disebut dengan mekanisme kontrol norma hukum (legal norm control mechanism). Ada tiga bentuk pengawasan atau pengendalian norma hukum dalam peraturan perundang-undangan, (Jimly Asshiddiqie, 2010 : 196) yaitu:

1. Kontrol yuridis, yaitu pengawasan/pengendalian peraturan perundangundangan melalui uji materil (judicial review). Dalam sistem peraturan perundang-undangan Indonesia untuk pengujian Undang-Undang dengan Undang-Undang Dasar menjadi kewenangan Mahkamah 
Konstitusi. Sedangkan untuk pengujian peraturan perundang-undangan dibawah Undang-Undang terhadap Undang-Undang menjadi kewenangan Mahkamah Agung.

2. Kontrol administratif, yaitu pengawasan atau pengendalian peraturan perundang-undangan oleh eksekutif atau lembaga administrasi yang menjalankan fungsi "bestuur" dibidang eksekutif. Dalam hal ini, misalnya kontrol administratif terhadap Undang-Undang berujung pada pengesahan oleh Presiden. Dalam hal Presiden terdapat hal yang luar biasa yang tidak memungkinkan Undang-Undang tersebut diberlakukan, maka Presiden berwenang mengeluarkan Peraturan Pemerintah Pengganti Undang-Undang yang "membatalkan" keberlakukan UndangUndang yang sudah disetujui Dewan Perwakilan Rakyat tersebut.

3. Kontrol politik, yaitu pengawasan atau pengendalian peraturan perundang-undangan oleh lembaga politik misalnya parlemen. Dalam hal ini perubahan Undang-Undang melalui jalur hak inisiatif sebagai amandemen dari Undang-Undang yang telah disahkan oleh Presiden.

Sebagai instrumen hukum negara, Peraturan Daerah yang bermasalah tersebut dapat dilakukan pengujian. Peraturan Daerah yang bertentangan dengan kepentingan umum atau bertentangan dengan peraturan yang lebih tinggi dapat diuji lewat dua model kewenangan yaitu dengan executive review (pengujian peraturan perundang-undangan yang dilakukan oleh pemerintah pusat) dan judicial review (pengujian peraturan perundang-undangan yang dilakukan oleh lembaga peradilan).

Pengujian Peraturan Daerah oleh Pemerintah (executive review), terdapat permasalahan yang patut untuk dikaji. Dalam pengujian Peraturan 
Daerah, Pemerintah Pusat mempunyai dua kriteria untuk melakukan pengujian, yaitu bertentangan dengan kepentingan umum dan bertentangan dengan peraturan perundang-undangan yang lebih tinggi. Berdasarkan Pasal 250ayat (2) UU Nomor 23 Tahun 2014 tentang Pemerintahan Daerah, pembatalan peraturan daerah yang bertentangan dengan kepentingan umum dilakukan oleh Pemerintah Pusat yang cakupannya meliputi:

a. terganggunya kerukunan antar warga masyarakat;

b. terganggunya akses terhadap pelayanan publik;

c. terganggunya ketentraman dan ketertiban umum;

d. terganggunya kegiatan ekonomi untuk meningkatkan kesejahteraan masyarakat, dan/atau;

e. diskriminasi terhadap suku, agama dan kepercayaan, ras, antargolongan, dan gender.

Pemerintah Pusat diberi kewenangan untuk membatalkan peraturan daerah, hal ini tercermin dalam ketentuan UU Nomor 23 Tahun 2014 tentang Pemerintahan Daerah Pasal 251 ayat (1) sampai dengan ayat (8), yang menyatakan sebagai berikut:

(1) Perda Provinsi dan peraturan gubernur yang bertentangan dengan ketentuan peraturan perundang-undangan yang lebih tinggi, kepentingan umum, dan/atau kesusilaan dibatalkan oleh Menteri.

(2) Perda Kabupaten/Kota dan peraturan bupati/wali kota yang bertentangan dengan ketentuan peraturan perundangundangan yang lebih tinggi, kepentingan umum, dan/atau kesusilaan dibatalkan oleh gubernur sebagai wakil Pemerintah Pusat.

(3) Dalam hal gubernur sebagai wakil Pemerintah Pusat tidak membatalkan Perda Kabupaten/Kota dan/atau peraturan bupati/wali kota yang bertentangan dengan ketentuan peraturan perundang-undangan yang lebih tinggi, kepentingan umum, dan/atau kesusilaan sebagaimana dimaksud pada ayat (2), Menteri membatalkan Perda Kabupaten/Kota dan/atau peraturan bupati/wali kota.

(4) Pembatalan Perda Provinsi dan peraturan gubernur sebagaimana dimaksud pada ayat (1) ditetapkan dengan keputusan Menteri dan pembatalan Perda Kabupaten/Kota dan peraturan bupati/wali kota 
sebagaimana dimaksud pada ayat (2) ditetapkan dengan keputusan gubernur sebagai wakil Pemerintah Pusat.

(5) Paling lama 7 (tujuh) Hari setelah keputusan pembatalan sebagaimana dimaksud pada ayat (4), kepala daerah harus menghentikan pelaksanaan Perda dan selanjutnya DPRD bersama kepala daerah mencabut Perda dimaksud.

(6) Paling lama 7 (tujuh) Hari setelah keputusan pembatalan sebagaimana dimaksud pada ayat (4), kepala daerah harus menghentikan pelaksanaan Perkada dan selanjutnya kepala daerah mencabut Perkada dimaksud.

(7) Dalam hal penyelenggara Pemerintahan Daerah provinsi tidak dapat menerima keputusan pembatalan Perda Provinsi dan gubernur tidak dapat menerima keputusan|pembatalan peraturan gubernur sebagaimana dimaksud pada ayat (4) dengan alasan yang dapat dibenarkan oleh ketentuan peraturan perundang-undangan, gubernur dapat mengajukan keberatan kepada Presiden paling lambat 14 (empat belas) Hari sejak keputusan pembatalan Perda atau peraturan gubernur diterima.

(8) Dalam hal penyelenggara Pemerintahan Daerah kabupaten/kota tidak dapat menerima keputusan pembatalan Perda Kabupaten/Kota dan bupati/wali kota tidak dapat menerima keputusan pembatalan peraturan bupati/wali kota sebagaimana dimaksud pada ayat (4) dengan alasan yang dapat dibenarkan oleh ketentuan peraturan perundang-undangan, bupati/wali kota dapat mengajukan keberatan kepada Menteri paling lambat 14 (empat belas) Hari sejak keputusan pembatalan Perda Kabupaten/Kota atau peraturan bupati/wali kota diterima.

Pasal ini dengan tegas menjabarkan kewenangan Menteri Dalam

Negeri yang berkaitan dengan pembatalan perda provinsi serta perda kabupaten/kota apabila Gubernur yang memiliki kewenangan untuk membatalkan perda tersebut tidak melakukan pembatalan. Mendagri juga memiliki kewenangan untuk menerima keberatan penyelenggara Kabupaten/Kota terhadap pembatalan Perda yang dilakukan oleh Gubernur, kewenangan Mendagri ini sangatlah lebih besar jika dibandingkan saat pengaturanya pada saat berlakunya UU Nomor 32 Tahun 2004 tentang Pemerintahan Daerah.

Mengingat sebelumnya pembatalan Perda dalam kaitannya pengawasan secara represif yang sebelumnya ada di dalam UU Nomor 32 Tahun 2004 tentang Pemerintahan Daerah Pasal 145 merupakan 
kewenangan Presiden, kini dengan dirubahnya UU Pemerintahan Daerah menjadi UU Nomor 23 Tahun 2014tentang Pemerintahan Daerah kewenangan pembatalan Perda semua beralih menjadi kewenangan Mendagri sehingga pembatalan perda bukan lagi menjadi kewenangan Presiden. Proses Raperda hingga pada tahap Perda mekanisme pembatalannya semua dilakukan oleh mendagri terhadap seluruh perda tanpa terkecuali sebagaimana yang diatur pada Pasal 251 UU Nomor 23 Tahun 2014 tentang Pemerintahan Daerah tersebut.

UU Nomor 23 Tahun 2014 tentang Pemerintahan Daerah memiliki berbagai perbedaan dan persamaan berkaitan materi yang diatur khususnya mengenai Pembatalan Perda. Persamaan dari pengaturan pembatalan perda ini dapat dilihat pada kewenangan yang dimiliki oleh Mendagri yakni Mendagri memiliki kewenangan pembatalan terhadap Ranperda APBD, pajak daerah dan retribusi daerah serta rencana tata ruang yang diatur pula dalam UU Nomor 32 Tahun 2004 tentang Pemerintahan Daerah Pasal 185 ayat (4) jo Pasal 189.

Perbedaan yang signifikan terjadi ketika melihat kewenangan Mendagri yakni adanya penambahan pembatalan yang masih bentuknya Raperda pada Ranperda RPJPD dan RPJMD serta mengenai kewenangan yang dimiliki Presiden dalam Pembatalan Perda. Sebelumnya dalam UU Nomor 32 Tahun 2004 tentang Pemerintahan Daerah, Presiden membatalkan seluruh Perda tanpa terkecuali. Pada UU No. 23 Tahun 2004 tentang Pemerintahan Daerah, kewenangan tersebut dilimpahkan kepada Mendagri sehingga Mendagrilah yang memiliki kewenangan untuk membatalkan Perda. Presiden hanya memiliki kewenangan terhadap 
keberatan yang diajukan pemerintah daerah terhadap pembatalan yang dilakukan oleh Menteri Dalam Negeri. Selain itu Mendagri juga berwenangan untuk membatalkan perda apabila Gubernur tidak melakukan pembatalan terhadap Perda yang diajukan oleh pemerintah Kabupaten/Kota serta menerima keberatan yang diajukan Pemerintah Kabupaten/Kota terhadap pembatalan perda yang dilakukan oleh Menteri Dalam Negeri.

Selain hal tersebut diatas, landasan hukum Mendagri dalam melakukan pembatalan perda yaitu adanya Instruksi Mendagri Nomor:582/476/SJ tentang Pencabutan/Perubahan Peraturan Kepala Daerah, Peraturan Kepala Daerah Dan Keputusan Yang Menghambat Birokrasi Dan Perizinan Investasi yang diterbitkan oleh Menteri Dalam Negeri Tjahjo Kumolo. Instruksi ini ditetapkan pada 16 Februari 2016. Dalam Instruksi Mendagri itu gubernur dan bupati/walikota di seluruh Indonesia perlu segera mengambil langkah-langkah untuk mencabut/mengubah perturan daerah, peraturan kepala daerah, peraturan kepala daerah dan keputusan kepala daerah yang menghambat birokrai dan perizinan investasi.

Gubernur melaporkan kepada Menteri Dalam Negeri melalui Sekretaris Jenderal Cq Kepala Biro Hukum Kementerian Dalam Negeri atas peraturan daerah, peraturan kepala daerah dan keputusan kepala daerah provinsi yang menghambat birokrasi dan perizinan investasi dengan mencantukan Judul, Bab, Bagian, Paragraf, Pasal dan Ayat untuk dibatalkan.

Bupati/Walikota melaporkan kepada Gubernur melalui Sekretaris Daerah Cq Kepala Biro Hukum Provinsi atas peraturan daerah, peraturan 
kepala daerah dan keputusan kepala daerah kabupaten/kota yang menghambat birokrasi dan perizinan investasi dengan mencantumkan Judul, Bab, Bagian, Paragraf, Pasal dan Ayat untuk dibatalkan.

Bupati dan Walikota melaporkan perkembangan pencabutan/perubahan peraturan daerah, peraturan kepala daerah dan keputusan kepala daerah kabupaten/kota yang menghambat birokrasi dan perizinan investasi kepada Gubernur setiap bulan pada Minggu Pertama.

Gubernur melaporkan peraturan daerah, peraturan kepala daerah dan keputusan kepala daerah kabupaten/kota yang telah dicabut/diubah dan peraturan daerah, peraturan kepala daerah dan keputusan kepala daerah provinsi yang menghambat birokrasi dan perizinan investasi kepada Menteri Dalam Negeri setiap bulan pada Minggu Kedua.

Dalam hal penyusunan pencabutan/perubahan peraturan daerah, peraturan kepala daerah dan keputusan kepala daerah, Pemerintah Daerah Provinsi dapat berkonsultasi dengan Biro Hukum Kementerian Dalam Negeri dan Pemerintah Daerah Kabupaten/Kota dapat berkonsultasi dengan Sekretaris Daerah melalui Biro Hukum Provinsi.

Standar pengujian perda oleh pemerintah berbeda dengan standar pengujian perda yang dilakukan oleh Mahakamah Agung. Bila Mahkamah Agung menguji suatu perda atas dasar apakah satu perda bertentangan atau tidak dengan peraturan yang lebih tinggi dan apakah prosedur pembuatan perda bertentangan dengan peraturan perundang-undangan, Pemerintah melakukan pengujian perda dilakukan dengan standar yang lebih luas. Dikatakan lebih luas karena pemerintah menguji perda tidak hanya didasarkan pada aturan hukum yang lebih tinggi dari perda, tetapi 
juga didasarkan pada standar kepentingan umum. Kepentingan umum adalah aspek yang bersifat sosiologis daripada yuridis. Sehingga pengujian terhadap kepentingan umum tergantung pada aspek keberlakuan berbagai macam jenis hukum dan norma sosial yang ada dalam masyarakat. Dalam penjelasan Pasal 250 ayat (2) Undang-Undang Nomor 23 Tahun 2014 tentang Pemeritah Daerah disebutkan bahwa yang dimaksud dengan melanggar ketertiban umum adaalah terganggunya kerukunan antar warga masyarakat, terganggunya akses terhadap pelayanan publik, terganggunya ketentraman dan ketertiban umum, terganggunya kegiatan ekonomi untuk meningkatkan kesejahteraan masyarakat, dandiskriminasi terhadap suku, agama dan kepercayaan, ras, antar-golongan, dan gender.

Namun hal itu adalah bahasa peraturan yang belum tentu sesuai dengan kondisi masyarakat. Bertentangan dengan kepentingan umum menjadi standar yang longgar yang ditafsirkan berdasarkan kekuasaan penafsir. Maka tidak jarang tafsir kepentingan umum lebih mewakili tafsir penguasa. Orientasi kekuasaanlah terkadang yang mewakili kepentingan umum. Hal ini dapat dilihat dimana ketika tidak terjadi gejolak atau penolakan terhadap berlakunya suatu perda di masyarakat juga dapat dibatalkan oleh pemerintah atas dasar bertentangan dengan kepentingan umum. Begitu pula sebaliknya, apabila suatu perda dianggap menimbulkan masalah oleh masyarakat dapat saja tidak dibatalkan oleh pemerintah bila perda tersebut sesuai dengan tafsir kekuasaan pemerintah. 


\subsection{Pembatalan Perda oleh Meteri Dalam Negeri}

Executive Review adalah pengujian peraturan daerah oleh Pemerintah yang lahir dari kewenangan pemerintah dalam rangka pengawasan dan pembinaan Pemerintah Pusat terhadap Pemerintah Daerah. Executive Review merupakan bagian dari sistem pengawasan dalam penyelenggaraan Pemrintah Daerah, khususnya pengawasan dalam produk legislasi daerah. Pengawasan Produk legislasi daerah (Perda) ini dilakukan agar materi muatan perda tidak bertentangan dengan peraturan yang lebih tinggi dan tidak bertentangan dengan kepentingan umum. (Fatkhurohman, 2013) Adanya kewenangan Pemerintah untuk melakukan pengujian Perda hendaknya tidak menjadikan jalan untuk mewujudkan superioritas kekuasaan Pemerintah Pusat atas Pemerintah Daerah dan hukum-hukum lokal yang diagregasi ke dalam bentuk Peraturan Daerah.

Sebenarnya bukan hanya Mendagri yang memiliki kewenangan untuk membatalkan Perda, akan tetapi Gubernur sebagai wakil Pemerintah Pusat di daerah juga diberi kewenangan yang sama. Pembagiannya adalah Mendagri berwenang membatalkan Perda Provinsi, sedangkan Gubernur berwenang membatalkan Perda Kabupaten/Kota. Secara yuridis, Mendagri dan Gubernur sebagai bagian dan wakil dari Pemerintah Pusat memang punya dasar justifikasi untuk melakukan kontrol terhadap produk hukum daerah. Fungsi kontrol Pemerintah Pusat tersebut dapat dipahami sebagai implikasi dari desain konstitusional otonomi daerah yang dibangun dalam bingkai prinsip Negara Kesatuan (unitary state/eenheidsstaat). Bingkai itu yang kemudian "memagari" pelaksanaan otonomi daerah di Indonesia, sehingga walaupun Pasal 18 ayat (5) UUD 1945 memberikan otonomi 
seluas-luasnya kepada Daerah, tanggung jawab akhir penyelenggaraan Pemerintahan Daerah tetap berada di tangan Pemerintah Pusat.

Merujuk kepada ketentuan Pasal 1 angka 7 dan 8 Undang-Undang Nomor 12 Tahun 2011 tentang Pembentukan Peraturan PerundangUndangan (UU PPP), Perda merupakan peraturan perundang-undangan yang dibentuk oleh Dewan Perwakilan Rakyat Daerah (DPRD) dengan persetujuan bersama Kepala Daerah. Kualifikasi Perda sebagai peraturan perundang-undangan dipertegas kembali dalam Pasal 7 ayat (1) huruf $f$ dan g UU PPP yang menyatakan Perda termasuk salah satu jenis peraturan perundang-undangan yang secara hirarki posisinya berda di bawah undangundang (UU).

Dengan kualifikasi yang demikian itu, seharusnya mekanisme pembatalan Perda tunduk pada ketentuan Pasal 24A ayat (1) UUD 1945 jo Pasal 9 ayat (2) UU PPP yang pada pokoknya mengatur mekanisme pembatalan peraturan perundang-undangan di bawah UU dilakukan melalui judicial review oleh Mahkamah Agung. Apabila mengacu pada ketentuan tersebut, maka jawaban atas pertayaan di atas sangat jelas, yaitu tidak tepat fungsi kontrol Pemerintah Pusat terhadap produk hukum daerah dimanifestasikan dalam bentuk kewenangan membatalkan Perda, sebab kewenangan itu seharusnya menjadi milik Mahkamah Agung. Akan tetapi, faktanya Pasal 251 Undang-Undang Nomor 23 Tahun 2014 tentang Pemerintahan Daerah telah memberikan kewenangan pembatalan Perda kepada Mendagri dan Gubernur (executive review), di sinilah terjadi anomali sistem ketatanegaraan. Ketentuan tersebut memperlihatkan bahwa undangundang memberikan kewenangan kepada Menteri yang dalam hal ini adalah 
Mendagri untuk membatalkan perda. Hal ini dikarenakan ada payung hukum yang mendasari dan memberikan kewenangan tersebut kepada Mendagri.

Untuk pengujian UU terhadap Undang-Undang Dasar dilakukan oleh Mahkamah Konstitusi sebagaimana diatur dalam Pasal 24C ayat (1) UUD 1945, sementara untuk pengujian peraturan perundang-undangan di bawah UU terhadap UU dilakukan oleh Mahkamah Agung sebagaimana diatur dalam Pasal 24A ayat (1) UUD 1945. Dengan demikian, UUD 1945 telah menegaskan hanya ada mekanisme tunggal untuk menguji suatu peraturan perundang-undangan yang telah diundangkan yaitu melalui proses judicial review, bukan executive review.Hal itu diperkuat dengan Pasal ( ayat (2) Undang-Undang Nomor 12 Tahun 2011 tentang Pembentukan Peraturan Perundang-Undangan yang menyebutkan bahwa dalam suatu peraturan perundang-undangan di bawah undang-undang diduga bertentangan dengan undang-undang, pengujiannya dilakukan oleh Mahkamah Agung.

Namun berbeda halnya jika kita melihat ketentuan sebagaimana yang termuat dalam Pasal 251 Undang-Undang Nomor 23 Tahun 2014 tentang Pemerintahan Daerah, yang pada intinya memberikan kewenangan kepada Mendagri untuk membatalkan suatu perda.Pembatalan Perda sendiri dilakukan oleh Mendagri, hal ini tentu saja mengalami suatu persoalan tersendiri yaitu pelaksanaan review tidak sejalan antara aturan dengan praktik. Review seharusnya dilakukan berjenjang. Mendagri melakukan review terhadap Perda provinsi, Gubernur terhadap Perda kabupaten/kota. Tetapi selama ini pembatalan selalu dilakukan Mendagri dalam bentuk Surat Keputusan. 
Selaku pemegang kekuasaan pemerintahan, Presiden seharusnya tidak bisa membatalkan Perda, apalagi dalam praktiknya dilakukan oleh Menteri Dalam Negeri. Pemerintah bisa menjadi pemohon pembatalan Perda. Membatalkan Perda sudah masuk kualifikasi kegiatan yudisial, sehingga tidak selayaknya dilakukan eksekutif. Itu sebabnya, kewenangan pembatalan Perda perlu dikembalikan kepada Mahkamah Agung. Meskipun demikian, bukan berarti eksekutif tidak bisa menjalankan fungsi pengawasan terhadap Perda. Pemerintah masih bisa melakukan pengawasan ketika masih berbentuk Rancangan Peraturan Daerah (Raperda). Jadi, Pemerintah bisa melakukan executive preview.

UU Pemda sebenarnya mengadopsi dua jenis pengawasan terhadap Perda, yaitu pengawasan preventif dan pengawasan represif. Pengawasan preventif diwujudkan dengan adanya evaluasi terhadap Rancangan Perda sebelum disahkan (pra-pengesahan). Sementara pengawasan represif diwujudkan dengan adanya mekanisme pembatalan Perda. Namun, kedua pengawasan tersebut berdasarkan UU Pemda yang saat ini berlaku dilakukan oleh Mendagri dan Gubernur. Inilah yang perlu diformulasi ulang, khususnya mengenai kewenangan Mendagri dan Gubernur yang terkait dengan pengawasan represif, karena sebagaimana dijelaskan sebelumnya hal itu tidak hanya menimbulkan anomali dalam sistem ketatanegaraan, tetapi juga bertentangan dengan UUD 1945.

Hal diatas memperlihatkan bahwa terjadinya disharmonisasi antar peraturan perundang-undangan yang mengatur tentang legalitas pembatalan perda, yakni Undang-Undang Nomor 12 Tahun 2011 tentang Pembentukan Peraturan Perundang-Undangan dengan Undang-Undang 
Nomor 23 Tahun 2014 tentang Pemerintahan Daerah. Adagium hukum mengatakan bahwa suatu peraturan perundang-undangan masih dianggap berlaku sebelum ada undang-undang yang mencabutnya. Sehingga kedua undang-undang tersebut dapat dijadikan sebagai landasan dalam upaya pembatalan suatu perda.

Namun untuk menjawab tentang undang-undang mana yang dirasa lebih "sesuai" sebagai landasan, tentunya kita harus mengacu pada kaidah penyusunan perundang-undangan yang berlaku. Dalam kaidah penyusunan perundang-undangan, jika terjadi disharmonisasi antara peraturan perundang-undangan setingkat, hal yang harus diperhatikan adalah pihak pemberi mandat undang-undang tersebut. Jika pembentukan salah satu undang-undang diantara undang-undang yang bertentangan merupakan amanat langsung dari UUD NRI 1945, maka undang-undang tersebutlah yang seharusnya dijadikan landasan utama dalam kehidupan hukum di Indonesia.

Apabila hal ini kita hubungkan dengan perdebatan mengenai keabsahan Mendagri dalam pembatalan perda, maka penulis ingin menyampaikan bahwa secara normatif Mendagri memiliki keabsahan dalam pembatalan perda karena berpayung hukum pada Pasal 251 UndangUndang Nomor 23 Tahun 2014 tentang Pemerintah Daerah. Akan tetapi, jika melihat berdasarkan kewenanangan, Mendagri bukanlah lembaga yang tepat dalam melakukan pembatalan perda, karena kewenangan dalam pembatalan perda telah diberikan oleh UUD NRI 1945 kepada Mahkamah Agung melalui Pasal 24A UUD NRI 1945. 
Agar perdebatan ini tidak berlanjut dikemudian hari, sekiranya para pembuat undang-undang untuk melakukan harmonisasi terhadap kedua undang-undang tersebut. Hal ini mengingat bahwa potensi perda yang bermasalah tidak hanya terjadi saat ini, tetapi dapat terulang di kemudian hari.

Dalam rangka perbaikan sistem pengawasan Perda ke depan, kewenangan Mendagri dan Gubernur sebaiknya dibatasi hanya untuk pengawasan preventif saja, yaitu dengan melakukan evaluasi terhadap Rancangan Perda sebelum disahkan (executive pre-view). Sementara untuk pengawasan represif, ketika suatu Perda telah berlaku dan mengikat umum, maka sebaiknya diserahkan kepada lembaga peradilan dalam hal ini Mahkamah Agung melalui mekanisme judicial review. Formula yang demikian selain berkesesuaian dengan amanat konstitusi juga memberikan fungsi kontrol Pemerintah Pusat terhadap produk hukum daerah secara proporsional.

Untuk mewujudkan formula yang demikian, bisa ditempuh dengan dua langkah yaitu dengan mengajukan uji materi terhadap ketentuan Pasal 251 UU Nomor 23 tahun 2014 tentang Pemerintahan Daerah kepada Mahkamah Konstitusi atau dengan melakukan revisi terhadap UU Pemda melalui proses legislasi oleh Pemerintah dan DPR. Langkah ini penting dilakukan mengingat Perda adalah instrumen utama pelaksanaan otonomi daerah. Apabila mekanisme pembatalannya tanpa melalui suatu proses pengujian di pengadilan, maka kesewenang-wenangan Pemerintah Pusat terhadap daerah sangat potensial terjadi yang pada gilirannya dapat mengancam eksistensi otonomi daerah itu sendiri. (M. Imam Nasef, 2016) 


\section{Kesimpulan}

Berdasarkan Pasal 251 Undang-Undang Nomor 23 Tahun 2014 tentang Pemerintah Daerah, Perda Provinsi dan peraturan Gubernur yang bertentangan dengan ketentuan peraturan perundang-undangan yang lebih tinggi, kepentingan umum, dan/atau kesusilaan dibatalkan oleh Menteri. Sedangkan untuk Perda Kabupaten/Kota dan peraturan bupati/wali kota yang bertentangan dengan ketentuan peraturan perundang-undangan yang lebih tinggi, kepentingan umum, dan/atau kesusilaan dibatalkan oleh Gubernur sebagai wakil Pemerintah Pusat. Apabila Gubernur sebagai wakil Pemerintah Pusat tidak membatalkan Perda Kabupaten/Kota dan/atau peraturan bupati/wali kota yang bertentangan dengan ketentuan peraturan perundang-undangan yang lebih tinggi, kepentingan umum, dan/atau kesusilaan, Menteri Dalam Negeri diberikan kewenangan untuk dapat membatalkan Perda Kabupaten/Kota dan/atau peraturan bupati/wali kota.

Secara yuridis normatif Mendagri memiliki keabsahan dalam pembatalan perda karena berpayung hukum pada Pasal 251 Undang-Undang Nomor 23 Tahun 2014 tentang Pemerintah Daerah. Akan tetapi, jika melihat berdasarkan kewenangan, Mendagri bukanlah lembaga yang tepat dalam melakukan pembatalan perda, karena kewenangan dalam pembatalan perda telah diberikan oleh UUD NRI 1945 kepada Mahkamah Agung melalui Pasal 24A UUD NRI 1945. 


\section{DAFTAR PUSTAKA}

Asshiddiqie, Jimly, 2006, Teori Hans Kelsen Tentang Hukum, Jakarta, Sekretariat Jenderal dan Kepaniteraan Mahkamah Konstitusi RI.

, 2010, Perihal Undang-Undang, Jakarta, PT. Konstitusi Press.

Bagijo, Himawan Etsu, 2009, Pembentukan Peraturan Daerah, Drafting Proficial Regulations bahasa.

Huda, Ni'matul, 2010, Problematika Pembatalan Peraturan Daerah, Yogyakarta, FH UII Press.

Soeprapto, Maria Farida Indrati, 2010, IImu Perundang-Undangan : Jenis, Fungsi, dan Materi Muatan, Yogyakarta. Kanisius.

Sunarno, Siswanto, 2006, Hukum Pemerintahan Daerah Di Indonesia, Jakarta, Sinar Grafika.

Yani, Ahmad, 2013, Pembentukan Peraturan Perundang-Undangan yang Responsif, Jakarta, Konstitusi Press.

\section{PERATURAN PERUNDANG-UNDANGAN}

Undang-Undang Dasar Negara Republik Indonesia Tahun 1945

Undang-Undang 23 Tahun 2014 Tentang Pemerintahan Daerah

Instruksi Mendagri Nomor:582/476/SJ tentang Pencabutan/Perubahan Peraturan Kepala Daerah, Peraturan Kepala Daerah Dan Keputusan Yang Menghambat Birokrasi Dan Perizinan Investasi

\section{JURNAL}

Fatkhurohman, Implikasi Pembatalan PerdaTerhadap Ketepatan Proporsi Teori Penegakan Hukum dalam Sistem Peradilan di Indonesia, Jurnal Dinamika HukumVol. 13 Nomor 1 Januari 2013.

\section{SUMBER LAIN}

Ahmad Yani, Gagal Paham Pembatalan Perda, http://nasional.sindonews.com/read/1120966/18/gagal-paham-pembatalan-perda1467280231, diakses pada tanggal 30 Juni 2016.

M. Imam Nasef, Anomali Pembatalan Perda, http/news.detik.com/read/2016/06/23/120229/3240276/103/anomali-pembatalanperda, diakses pada tanggal 22 Oktober 2016 